\title{
The Elimination of the Judge's Mandate and Its Effect on the Civil Judiciary
}

\section{La eliminación del mandato del juez y su efecto en el poder judicial civil}

\author{
Fwrat Rostam Ameen Al-Jaf
}

Collage of Law and Political Sciences Kirkuk University, Iraq

ORCID: https://orcid.org/0000-0002-8004-0867

*Correspondence

Email: fwrat.rostamameen@uokirkuk.edu.iq
Cite as:

Ameen Al-Jaf, F.R. (2020). The Elimination of the Judge's Mandate and Its Effect on the Civil Judiciary. Propósitos y Representaciones, 8 (SPE2), e638. Doi: http://dx.doi.org/10.20511/pyr2020.v8nSPE2.638 


\section{Summary}

The function of the judiciary is to protect the law system and the law rights and centers by a request applied to it by the concerned persons, and by issuing decisions and verdicts that remove the state of ignoring which surrounds the right or the law center wanted to be protected in which it gets the binding force of the thing judged owing to its issue which prevents the review of the dispute among the same fellows for the same subject and cause. For the judicial verdict to get the binding force of the thing sentences, it must be issued by a judge in limits of his judicial sponsorship, also, it must be issued in the legally decided form. So, If the judicial sponsorship removed from the judge, for any reason, there will be important results that we will deal with them in this study. And since the Iraqi Law of civil pleadings did not address this issue, we will try in this study to find the best legal ways to address the above topic.

Keywords: Court Order; Psychological Proposal; Civil Judge, Psychology of Justice.

\section{Resumen}

La función del poder judicial es proteger el sistema legal y los derechos y centros legales mediante una solicitud que le apliquen las personas interesadas, y emitiendo decisiones y veredictos que eliminen el estado de ignorar que rodea el derecho o el centro legal que desea estar protegido en el que obtiene la fuerza vinculante de la cosa juzgada debido a su problema que impide la revisión de la disputa entre los mismos compañeros por el mismo tema y causa. Para que el veredicto judicial obtenga la fuerza vinculante de las sentencias, debe ser emitido por un juez dentro de los límites de su patrocinio judicial, además, debe emitirse en la forma legalmente decidida. Entonces, si el patrocinio judicial se retira del juez, por cualquier motivo, habrá resultados importantes que trataremos con ellos en este estudio. Y dado que la Ley iraquí de alegatos civiles no abordó este tema, intentaremos en este estudio encontrar las mejores formas legales para abordar el tema anterior.

Palabras clave: Mandato judicial; Propuesta psicológica; Juez civil, Psicología de la justicia.

\section{Introduction}

The function of the judiciary is to protect the law system and the law rights and centers by a request applied to it by the concerned persons, and by issuing decisions and verdicts that remove the state of ignoring which surrounds the right or the law center wanted to be protected in which it gets the binding force of the thing judged owing to its issue which prevents the review of the dispute among the same fellows for the same subject and cause.

An effective justice system is a fundamental right of citizens, as well as underpinning business confidence, job creation and economic growth. Enabling entrepreneurs to protect their rights, settle their contracts, and recover their debts is vital for enterprise, investment, innovation and fair competition. Across the EU, mutual understanding and trust in justice systems - their quality, independence and efficiency - is essential to the functioning of the internal market. This theme looks at how judiciaries assess their functioning, quantitatively and qualitatively, to inform ongoing improvements and innovations. In that respect, it is important to underline that any justice reform should uphold the rule of law and comply with European standards on judicial independence. This theme also looks at ways in which access to justice is being enhanced throughout the 'chain of justice': at the point of entry, during the judicial process, and at its conclusion. It explores the modernisation of judicial administrations, including the role of Information and Communication Technologies in courts, better communication and consultation, user-centric processes, judicial training and continuing professional development. 
An effective justice system is a fundamental right of citizens, as well as underpinning business confidence, job creation and economic growth. Enabling entrepreneurs to protect their rights, settle their contracts, and recover their debts is vital for enterprise, investment, innovation and fair competition. Across the EU, mutual understanding and trust in justice systems - their quality, independence and efficiency - is essential to the functioning of the internal market. This theme looks at how judiciaries assess their functioning, quantitatively and qualitatively, to inform ongoing improvements and innovations. In that respect, it is important to underline that any justice reform should uphold the rule of law and comply with European standards on judicial independence. This theme also looks at ways in which access to justice is being enhanced throughout the 'chain of justice': at the point of entry, during the judicial process, and at its conclusion. It explores the modernisation of judicial administrations, including the role of Information and Communication Technologies in courts, better communication and consultation, user-centric processes, judicial training and continuing professional development.

The positive impact of national justice systems on the economy is underlined in literature and research3, including from the International Monetary Fund,4 the European Central Bank, the OECD,5 the World Economic Forum, and the World Bank, and the European Commission's September 2014 paper on "The Economic Impact of Civil Justice Reforms".

The EU Justice Agenda for Europe 2020 - Strengthening Trust, Mobility and Growth within the Union highlights the contribution of EU justice policy to supporting economic recovery, growth and structural reforms. "The EU has taken action to progressively build the trust necessary for businesses and consumers to enjoy a single market that truly works like a domestic market. Red tape and costs have been cut: a judgement given in one Member State can now be recognised and enforced in another Member State without intermediary procedures (the formality of 'exequatur' 6 has been progressively removed in both civil and commercial proceedings)".

Whatever the model of the national justice system or the legal tradition in which it is anchored, independence, quality and efficiency are the essential parameters of an effective justice system and need to be ensured.

Each EU Member State has its own legal tradition and unique judicial system to administer civil, criminal and administrative law. While these specificities will always remain, there is a shared interest across the EU-28 that each justice system is of quality, independent and efficient. Businesses and citizens need to be assured that, as a final resort, they can seek redress from the courts in a reasonable timescale, to a consistent standard, and without outside interference in the process of judgement at home and throughout the EU. Actual recourse to the law is less important than potential recourse: the knowledge that these safeguards exist. Effective justice contributes to strengthening Member States' mutual understanding and trust in each other's judicial systems, which is also the aim of the European Commission's Justice Programme for 2014-2020.

So, the judicial verdict is considered as the most important stage of the case because it is the main aim that the fellows try to get it to grant their law rights and centers. Therefore, the law of the civil pleadings is interested with the rules in terms of their procedures, organization and the stages of their issues. For the judicial verdict to get the binding force of the thing sentences, it must be issued from a judge in limits of his judicial sponsorship. Also it must be issued in the legally decided form. So, if the judicial sponsorship removed from the judge for any reason, there will be important results that we will deal with them in this study. 


\section{Problem of the Study}

The main problem of the study is represented by the fact that the civil case consists of some judicial procedures initiating with building up a lawsuit till the issue of the decisive verdict in it. For the judicial verdict to get the binding force of the thing judged, it must be issued from a judge in limits of his judicial sponsorship. So, if this sponsorship is removed from the judge during the period between the building up of the lawsuit and the issue of the verdict in it, important results and signs will arise. Since the active the Iraqi civil Law of Pleadings has not dealt with this subject, we have chosen it as a subject for our study.

Measuring the effectiveness of justice systems is not an easy exercise. Justice cannot just be measured in, for example, the number of court cases or judgments. Timeliness of outcome is a fundamental right for all parties which demands efficiency ('justice delayed is justice denied'), but too great an emphasis on the speed of the process can lead to miscarriages of justice ('justice hurried is justice buried'). An effective justice system thus requires taking into account three essential aspects, namely: the quality of the justice system, its independence, and the efficiency with which it operates. In recognition that these three factors are inseparable, and to provide an overarching perspective, the EU Justice Scoreboard was first launched in 2013 as an information tool to achieve more effective justice by providing objective, reliable and comparable data on justice systems in all Member States on an annual basis. The EU Justice Scoreboard contains information on all three main elements of an effective justice system: quality, independence and efficiency. The EU Justice Scoreboard feeds the European Semester, the EU's annual cycle of economic and structural policy coordinate. The context for the Scoreboard is the process of ongoing reform in many Member States to render their justice systems more effective for citizens and businesses, which has also been an integral part of Economic Adjustment Programmes since 2011. The improvement of the quality, independence and efficiency of judicial systems has also been a priority since 2012 for the European Semester, the EU's annual cycle of economic policy coordination, as signalled in the Annual Growth Surveys7. The Scoreboard feeds the European Semester process by providing objective data concerning the functioning of the national judicial systems. This contributes to identifying issues that deserve particular attention to ensure implementation of reforms. The Commission publishes a series of thematic factsheets on public administration under the European Semester, including a factsheet on effective justice systems

\section{Plan of the Study}

This study is divided into two requests. So, in the first request, we talk about what meant by the judge's sponsorship and the cases of its removal. In the second request, we deal with the consequences of the removal of the judge's sponsorship, and we have finished the study with some conclusions and suggested recommends.

Before you can strengthen the quality of any system, you need to understand its functioning - its strengths, stress points and bottlenecks. In seeking to drive up standards, the starting point is to find out the current position and the factors behind it, to feed this information into forward planning, and to follow changes over time (see also topic 1.3).

All Member States are now engaged in some form of performance measurement and monitoring, using indicators - and increasingly ICT - to gather and analyse information on the effectiveness of the justice system. Increasingly, this assessment is going from the quantitative into the qualitative, based on internal and external dialogue with court users to answer the questions:

Is the justice system performing to expectations, demonstrating efficiency and delivering quality outcomes? If not, what needs to change? 
Raw data is important, but it needs interpretation. This has led judiciaries to employ techniques such as establishing quality groups from within the system (judges, prosecutors and court staff), to consult citizens and other court users (lawyers, notaries, expert witnesses, etc.) and to introduce quality management systems found elsewhere in the public and private sectors, which emphasise an ongoing process of feedback, reflection and improvement.

\section{Monitoring and evaluation}

Member States are increasingly using performance data to assess and improve the efficiency of their justice systems. Regular monitoring of daily court activity is commonplace in all EU Member States, according to the 2016 EU Justice Scoreboard:

All but three Member States gather data on the number of incoming civil, commercial and administrative cases. All but four track the length of proceedings. 27 Member States have a variety of tools in place aiming to monitor and evaluate court activities, including annual activity reports, monitoring the number of postponed cases or specialized court staff for quality. 19 of the 28 Member States have standards in place related to active monitoring of case progress.

\section{The First Request}

\section{What Meant by the Judge's Sponsorship and the Cases of Its Removal}

Article (29) of the Pleading Civil Law, No.(83) for (1969) provides that: the sponsorship of the civil courts goes on all the persons, natural and artificial, including the government and it specializes in settlement in disputes except those that have been excluded by a special version and it came in the principle in the third item.

For that, the sponsorship of the judiciary creates the judicial protection for everyone wants, and on any person either natural or public artificial or special including the government. The validity of the judicial verdict must issue from a court formed legally. The formation of the government must subject to a decision issued from the Higher Judicial Council specifying the judges obliged to work in the different courts. The judge cannot exert his work without issuing a decision obligating him to work in this court, or his verdict will be null absolutely related to the general system because the verdict has issued from a judge whom has not granted the judicial sponsorship to settle in the case or the cases that he issues or contributes to issuing a verdict through them (Abdu-Al-Rahman, 2011).

So, we will divide this request into the following types:

- The First Type: What Meant by the Sponsorship of the Judge and How to Get It

- The Second Type: The Cases of the Judge Sponsorship Removal.

\section{The First Type}

\section{What Meant by the Sponsorship of the Judge and How to Get It}

Linguistically, sponsorship means nearness and the verb sponsor means to take responsibility regarding something, and the noun welaya, in genitive, as Arabic word, refers to authority (AlRazi, 1983).

The performance of the justice system goes beyond efficiency, of course. As highlighted in the introduction, justice is not just a case of timely judgements, but also robust ones. The experience of the Rovaniemi courts in Finland is illustrative in establishing a set of quality criteria as benchmarks for the court system, of which 'promptness' was only one aspect. The Quality 
Project set up quality groups to facilitate a discussion over critical performance issues within the judicial system - which can involve judges, court administrators, prosecutors and their staff - in a process of evaluation and improvement. The Quality Project won the "Crystal Scales of Justice" Award in 2005.

As a public service, the judiciary is ultimately accountable to the citizenry. In the words of the European Court of Human Rights (ECtHR), "public confidence in the judicial system ... is clearly one of the essential components of a State based on the rule of law". Among the factors identified by ECtHR that might undermine this crucial confidence are "the persistence of conflicting judgments [which] can create a state of legal uncertainty", "the administration of justice in secret with no public scrutiny", "actual bias [or] any appearance of partiality" and failure to incorporate safeguards of the independence and impartiality of the judiciary "into everyday administrative attitudes and practices".

Once the public loses faith in the judicial system, due to inconsistent decision-making (whether actual or perceived) or perceived lack of independence, it is hard to rebuild that trust. Increasingly, European judiciaries recognise the value of dialogue in maintaining a consensus that justice is being delivered and is seen to be done. If legitimate concerns materialise, then remedial action can be taken in time. This requires courts to become outward-looking and to view the carriage of justice as a service to the public. This raises three questions:

What do users expect from the justice system? What standards of service delivery should courts be setting? Does the service match those expectations and standards?

Across the EU and beyond, satisfaction surveys are increasingly commonplace - not with the outcome of judgements, of course, but with the system and the process (before, during and after). The 2017 EU Justice Scoreboard finds that, in 2015, 13 Member States conducted surveys among court users or legal professionals and 14 of them undertook a follow-up to the surveys undertaken. It included a broad range of activities such as using survey results as input for an annual/specific report, or for an evaluation of the justice system or for modifying/improving the functioning of certain courts etc. CEPEJ has produced a model survey and methodological guidance.

Idiomatically, it is the power that is granted to the judge to settle in disputes among the individuals according to the law (Al-Nadawi, 2009).

For the judicial verdict to be valid, it must be issued from a court formed legally and from judges having judicial sponsorship.

Because of the important role that the judges play and the responsibility that they bear, the legislations in choosing the judges differ from one country to another according to the difference in the political, social, regional and economic circumstances for each country. The ways of choosing can be classified into:

1. In common choosing: according to this way, the choosing of the judges is done by the judicial corporation itself. This way is followed in Belgium (Al-Nadawi, 2009).

2. Public election: according to this way, the choosing of the judges is done through the election, as in the U S A, Swiss and United Russia (Al-Aboodi, 2000).

3.The choosing of judges done by the designation by the government. In this way, the judges are designed by the Executive Authority, as in France and Egypt. In Iraq, the Higher Judicial Council nominates the qualified for designation from the graduates of the Judicial Institute (The Law of Judicial Institution, No.33 for 1976), and then sends the names list of nominees to the presidency of the republic to issue a republic decree concerning that (The Law of The Higher Judicial Council, No. 45 for 2017). 


\section{The Second Type}

\section{Cases of the Removal of Judge's Sponsorship}

For the judicial verdict to be valid, it must be issued from a court formed legally, in addition to that, it must be issued from a judge having judicial sponsorship. But this sponsorship may face obstacles or cases lead to its removal either in an absolute and final way or in a temporarily and relative way.

Quality criteria, internal dialogue through quality groups, and external consultation on service performance are all building blocks for total quality management (TQM) within organisations (see topic 4.2). In common with many public administrations throughout Europe, EU judiciaries are turning to quality management systems (QMSs) to strengthen their service delivery and resource management.

As an example, the courts system of Lithuania (below) has drawn on several QMS models, including ISO 9001 (the international standard popular in both the private and public sectors), the Common Assessment Framework and the Customer Service Standard. The goal is not just to improve the quality of the work and services provided by the judicial system and the National Courts Administration, but also to enhance public trust in these institutions (except judicial activity while administering justice, which is solely in accordance with the law).

So, we will deal with this subject in two paragraphs:

\section{First: The Temporary or Relative Removal for the Judge's Sponsorship.}

Some obstacles or circumstances that lead to the removal of the sponsorship temporarily may occur in the judge's sponsorship when looking at the civil case. He will remain a judge, but with the change of the spatial specialty for exerting his sponsorship or limiting this exertion so he cannot look at the cases shown to him. Access to an effective justice system is a fundamental right under the EU Charter of Fundamental Rights and the ECHR, as well as the foundation of a functioning democracy and prospering economy. This accessibility is put at risk when court proceedings are too intimidating, too hard to understand, too expensive, or too time-consuming. It is undermined when the legal representatives of citizens and businesses are not able to get full and easy access to case law which allows them to perform as advocates. Good practice dictates that judiciaries search for ways to explain court processes and judgments in plain language, to inform the general public and lawyers on legal precedents, and to promote voluntary alternatives to court which are potentially faster, cheaper and more conciliatory in the service of justice. The obstacles or circumstances that lead to the removal of the sponsorship temporarily are the change of the spatial or qualitative specialty, or the invalidity of the judge for judiciary or preventing him to settle in some cases or preventing him temporarily to look at the cases as a whole (The Judicial Organization Law, No.160 for 1979), so we will talk about these cases as the following:

\section{The Change of the Spatial Specialty of the Judge}

The change of the spatial specialty of the judge may happen by transferring him to another court whether the transference is inside the appeals area or outside it. So, he must be transferred from the province or the city or the district he works in into another province. But this transference must subject to some conditions, so the judge with the fourth rank cannot be transferred to any places except the towns and districts. Also, the judge cannot be transferred before he spends three years in one place. The judge with the fourth or third or second rank also cannot stay without transference for more than five years (The Judicial Organization Law, No.160 for 1979). 
It is worth noting that the transference is either by a request from the judge or from the head of the Appeals Court and by issuing a decision from the Higher Judicial Council.

\section{The Change of the Qualitative Specialty for the Judge}

The judge can be transferred from one court to another in the same appeals area. As we noted before, one or more courts of first instance must be established in the center of each province or town. It can be established in districts by a statement issued from the head of the Higher Judiciary. Usually, when the Court of First Instance forms, some establishments also form with it like the Court of Personal Status, the Court of Investigation, the Court of Misdemeanors in addition to any court needs to be formed. So, it is possible to transfer the judge from the Court of First Instance into the Court of Personal Status in the same town or district, in this case, the spatial specialty has not changed, but the change has occurred in the qualitative specialty, i.e. his judicial sponsorship concerning the court of first instance has removed and has got a new sponsorship in the Court of Personal Status (The Judicial Organization Law, No.160 for 1979).

Justice is better served when legal representatives have all necessary information to present their cases fully and represent their clients' interests fairly, and judges are fully informed on relevant case law at the European level before making pronouncements. The 2017 EU Justice Scoreboard shows that 26 Member States have put in place a non-restricted open access of judgements free of charge. In all of these countries, the online information is updated at least once a month. EU case law is transforming national law in the fields of administrative, labour, civil and commercial law, as noted by the Spanish Judicial Network in 2012.

Several Member States have introduced systems to collect and disseminate EU case law around their national court systems. The pioneer in this regard was the Netherlands' Eurinfra model, which was launched in the early 2000s. Others have followed the Dutch lead by establishing their own network of court coordinators to act as key reference points on EU Law (Belgium, Bulgaria, Czech Republic, Denmark, Italy, Romania and Spain). In many cases, like the Dutch example, this network is complemented by European judicial training (see topic 7.4) and/or underpinned by databases and dissemination of information.

\section{The Invalidity of the Judge for Judiciary}

When the judge exerts his work as a judge, the case shown to him can have some circumstances and confusions that may affect his psychology and then affect the verdict of the case. To protect the judge from himself and from the people and to protect the people from him, the legislator put some legal versions that solve this problem and they obliged the judge not to look at the case in certain cases. The law also allows for any party of the case to get the request of the judge's answer for the case in certain situations (Al-Namr, 1982).

The use of alternative dispute resolution (ADR) methods is a question of justice policy that has important consequences for both the quality and efficiency of judicial outcomes, by providing a voluntary alternative to court proceedings to resolve cases. In principle, ADR methods have many advantages over litigation in civil, commercial or administrative cases. It usually reduces costs to the parties, offers greater flexibility in procedure, provides more privacy and control to the parties, may result in speedier resolutions, and settles on solutions which should meet each side's interests. For the judiciary, ADR methods frees up court time and saves costs. The 2017 EU Justice Scoreboard showed that all 26 Member States with available data promote and incentivise the use of ADR methods in civil and commercial disputes, 25 in labour disputes, and 24 countries in consumer disputes, although the intensity of promotion/incentives varies. 
The Temporary Removal for the Judge's Sponsorship Concerning Looking at All Cases

The judge's sponsorship may be removed from looking at the cases temporarily through building up the disciplinary case against him. If the committee of the judges' affairs in the higher judicial council during looking at the case found that the act belonging to the judge is a felony or a misdemeanor, it will decide to send him to the special court and sends all the papers after the head of the Higher Judicial Council suspends the judge according to the Law of the Discipline of State Employees (The Judicial Organization Law, No.160 for 1979).

\section{Secondly: The Absolute or Final Removal for the Judge's Sponsorship}

The judge may face some situations or circumstances that lead to the removal of judicial sponsorship in a final and absolute form so he will not remain as a judge (Alam, 2013). The cases that cause the removal of the judge's sponsorship in a final form is the death, the end of the service, retirement, the transference to a civil employment outside the town. There are some states that the judge is not allowed to look at some cases in a final form also, so we will show these states briefly:

\section{The Death}

The personality of the human begins when he is born and ends with his death. So, it is natural to remove the judge's sponsorship when he dies (The Probation Law No.107 for 1979).

\section{The End of the Service}

If a judge having punishment against a verdict and issued from a special court because of an action does not fit the honor of the judicial employment, or if a committee of the judges' affairs states his invalidity to continue in the judicial service, so the committee decides to end the judge's service (The Judicial Organization Law, No.160 for 1979). Then, the Higher Judicial Council takes his decision to suspend the judge till the republic decree issues. In this case, the judge's sponsorship removes in a final form begins from the date of the decision regarding the suspension of the Civil Retirement Law.

\section{The Retirement and Resignation}

a. Retirement: The judge's sponsorship removes when he retires after completing the age of sixty-three, and he can retire before that according to his request according to the rules of the Civil Retirement Law (The Judicial Organization Law, No.160 for 1979).

b. Resignation: The judge can resign from his employment by a written request to his reference (The Higher Judicial Council) and this reference must take its decision during a period does not exceed thirty days. The judge is regarded untied when the period of time ends unless the order of acceptance issues after that (The Probation Law No.107 for 1979). Therefore, the judge's sponsorship removes if there is a decision issued from the Higher Judicial Council or after the end of the thirty days that are legally specified.

\section{The Transference to a Civil Employment outside the Town}

The judge's sponsorship ends when he is transferred to another civil employment outside the town in which the higher council can transfer the services of the judge with the fourth class to a civil employment according to a decision confirming that he is not qualified for judgment. A decision of the suspension of the judge is issued till the issue of the republic decree for his transference to a civil employment with the knowledge of that his sponsorship ends from the date of the issue of the suspension decision (The Judicial Organization Law, No.160 for 1979). 


\section{Preventing the Judge from Looking at Some Cases}

There are some situations in which the judge is forbidden to settle in some cases and then his sponsorship removes even it is still valid compared with the others. So, the judge who is not Muslim cannot run the court of the personal status, or contribute to the corporations related to the personal status for the Muslims. So, the prevention includes all the cases concerned with the personal status for the Muslims. The judge who is not Muslim will not take any sponsorship in these cases (The Judicial Organization Law, No.160 for 1979).

\section{The Sfcond Request}

\section{The Affection of the Removal of the Judge's Sponsorship}

The issuing judicial verdict or the verdict which will issue in the cases shown to it owing to the removal of the judge's sponsorship has important legal signs. These signs differ whether the removal of the sponsorship is before the pleading end or after the pleading end and before issuing the verdict in it.so, we will divide the request into the following types:

The First Type: The removal of the judge's sponsorship during the pleading and before its end

The Second Type: The removal of the judge's sponsorship after the pleading end

\section{The Removal of the Judge's Sponsorship during the Pleading and before its End}

The judge's sponsorship concerning looking at the case may be removed during the pleading and before the court decision. Here a question will arise about the procedures taken by the judge, if they are cancelled or nullified, or stay in consideration for the judge who succeeds him. The affair differs whether these procedures are concerned with the public system or not.

We will try in this type to shed light on these procedures and on how the judge's sponsorship affects them through the following paragraphs:

\section{Firstly: The Affection of the Removal on the Procedures Concerned with the Public System}

During the show of the case in front of the court and for the verdict to be issued, the judge must take some procedures obligated by the law. These procedures are various and many. For example, building up a secret pleading in circumstances that the court cannot make the session secret. The other procedure is that the court does not ask the fellow who was incapable of proving his lawsuit to make his fellow take an oath or not (The Pleadings Civil Law, No.38 for 1969). Also, one of these cases is when the judge takes a procedure without informing the other parties which deprives them from the right of the sacred defense, or forming the court of appeals consists of two judges instead of three, or violating the legal rules concerned with the session system (A'abdeen, 2013). The question that is arisen: Are these procedures that the ancestor judge did in consideration for the successor judge?

To answer this question, we want to state firstly that the Pleading Civil Law has not talked about this subject. Secondly, there are two states that must be differentiated, the first one is if the procedures done by the ancestor judge suit the law, the successor judge can depend on these procedures and does not cancel or restore them. the second one is if the ancestor judge commits a contravention, the successor judge must restore the procedures because of their nullity (The Pleadings Civil Law, No.38 for 1969). 


\section{Secondly: The Affection of the Removal on the Procedures not Concerned with the Public System}

They are the procedures decided for the service of the fellows, so the court does not talk about them spontaneously unless the fellows want that. There are many examples of these procedures in the civil pleading law. For example, the articles (46) and (50) of the law referred about the data that must be found in the case request or the codes or the photos of documents, also the rules which are concerned with the spatial specialty (The Pleadings Civil Law, No.38 for 1969).

The question here is about the commitment of the successor judge concerning the procedures done by the ancestor judge. Since the Pleading Law has not solved this case, so we see that the successor judge can acknowledge these procedures and does not restore them since they are not concerned with the public system, and there is no affection on the path of the case since just the fellows have the right to make a contestation for these procedures (Al-Majeed Bakr, 2013).

\section{The Removal of the Judge's Sponsorship after the Pleading End}

The judge's sponsorship may remove from looking at the case after the court to end the pleading, so does this situation affect the verdict which will issue in the case?

Article (156) of the Pleading Civil Law provides that if the case is ready to issue the verdict, the court decides to end the pleading, and then it issues its verdict in the same day, or determine the utterance of the verdict in another time not exceeding fifteen days from the date of valuation of the pleading end.

Here, another stage begins, it is the stage of consultation among the judges. It is noticed that the Pleading Civil Law has not talked about the consultation directly, but it suffices in the reference to the fact that the verdicts are issued by the agreement of opinions or by the majority (The Pleadings Civil Law, No.38 for 1969). It also has not dealt with the state of the removal of the sponsorship of one of the judges and its affection on the verdict that will issue in the case.

This stage is considered as one of the important stages concerning issuing the verdict in which the verdict cannot be issued when the sponsorship of one of the judges is removed. So, the corporation must be completed by another judge and opening the door of pleading again so that the pleading can happen in front of the who judge who took the place of the judge whose sponsorship removed for any reason. Then the amending of the pleading will be recited and the parties of the case or their agents ratify on it, and then the court decide the pleading end and issues its verdict (Abu-Al-wafa, 2010).

It is worth mentioning that the Iraqi Law of the Code of Criminal Proceedings dealt with the article 161 the state of the change of the judge and the procedures that must be followed in this side, so we will suggest adding an item to the law of the Iraqi civil pleading to solve this situation.

\section{Results}

After finishing the study, we have got the following results and recommends:

1.We got through the study what meant by the judicial sponsorship and the states of getting this sponsorship and its conditions. 
2.The removal of the judge's sponsorship may be temporarily or relative, or final or absolute.

3. The removal of the judge's sponsorship during the pleading and before its end, and its affection on the procedures concerned with the public system and the procedures not concerned with the public system.

4.The affections because of the removal of the judge's sponsorship after the pleading end.

\section{Recommendations}

We recommend to add an article to the second book / the first section (the verdicts) the first chapter - public verdicts and as follows:

- Only the judges who took part in the consultation can take part in the consultation or the verdict will be null.

- Adding an item to the first book / the fourth section - the system case are as follows: If a judge looked at the case and another judge took his place before issuing the verdict in it, the successor judge can depend in his verdict on the procedures the ancestor judge did or restore these procedures himself.

- Adding a paragraph to article (157) to be as follows: When a judge takes the place of another judge and before uttering the verdict, the door of the pleading must be opened and then its amending must be recited and the parties of the case or their agents ratify the case and then the court decides to end the pleading and issues its verdict.

\section{References}

A'abdeen, M. A. (2013). Voiding of Verdicts. Alexandria: Al-Ma'aref Institution, Abdu-Al-Rahman, M. S. (2011). The Judicial Verdict. Beirut, f1: Al-Halabi Legal Publications, Abu-Al-wafa, A. (2010). Verdicts Theory in the Pleading Law. Alexandria: Al-Mma'aref Institution,

Al-Aboodi, A. (2000). Explanation of the Rules of Pleading Law. Iraq: Mosul University. Alam, R. I. (2013). The Nonexistent Judicial Verdict. Alexandria: Al-Wafaa Liberary, Al-Majeed Bakr, E. A. (2013). The Proceedings of Civil Pleadings. Erbil: Jiha University. Al-Nadawi, A. W. (2009). The Civil Pleadings. Cairo: Al-A'atek for Producing Books, Al-Namr, A. (1982). The Pleadings Law. Cairo: House of University Culture.

Al-Razi, M. (1983). Mukhtar Al-Sahah. Kuwait: House of Al-Resala, The Judicial Organization Law, No.160 for 1979, The Amended.

The Law of Judicial Institution, No.33 for 1976, The Amended.

The Law of The Higher Judicial Council, No. 45 for 2017.

The Pleadings Civil Law, No.38 for 1969, The Amended.

The Probation Law No.107 for 1979, The Amended. 